\title{
THE DISAPPEARANCE OF ZOSTERA MARINA
}

\author{
By W. R. G. Atkins, Sc.D., F.R.S. \\ Head of the Department of General Physiology at the Plymouth Laboratory
}

In his paper on "The autecology of Zostera marina in relation to its wasting disease", Tutin (1938) states that "In the British Isles the year I93I-2 showed a sunshine deficiency of about $20 \%$ below normal, and no other year in the past ten showed a deficiency approaching this. The scanty figures available for other countries suggest that this unusual lack of sunshine was a general phenomenon, though in some countries it was less pronounced but of longer duration." His enquiries showed that about I93I there was extensive mortality on the Atlantic coast of the U.S.A., though there was some evidence of a local decline in 1930. A year later, in 1932, Zostera had practically disappeared at Beaufort, North Carolina and as far north as Nova Scotia. In 1933 scarcity spread still farther northward to all localities in Canada. At Plymouth, England, the plant is believed to have begun to decrease towards the end of I93I. In $\ 6$ of his summary Tutin writes: "It is suggested that the enfeeblement of the plant due to lack of sunshine in $193 \mathrm{I}-2$ is the fundamental cause of the epidemic, and that recovery depends on the regeneration of the plant from seed and is therefore likely to proceed slowly."

It appeared desirable that this interesting suggestion should be tested by an extension of the examination of the meteorological records beyond ten years, as far as they go, namely back to 1897 , and that the alleged $20 \%$ deficiency should be checked. Accordingly, taking the sunshine normals as revised up to 1928, the amounts of sunshine received each year in each of the twelve districts of the British Isles were tabulated as percentages of the normal. As is customary mean values were obtained for the districts I-IO, namely excluding the north of Scotland (0) with adjacent islands, and the English Channel Islands (II). It appears unnecessary to give all the figures, especially as since 1928 such percentages have been published by the Meteorological Office on the 1928 basis, but the following comments may be made upon the records from I897-1937 inclusive. The most striking thing in the series is the uniformity of the results. As regards low values, in I898 Ireland S. had $8 \mathrm{I} \%$ of its normal sunshine. In 1900 and 1902 England N.E. had $84 \%$, as had also Scotland E. in I902. The year I9I2 gave conspicuously low values, and averaged $83 \%$ for the ten districts, Scotland E. and England N.E. showing 76 and $78 \%$ respectively. In I9I6 districts $0-4$ inclusive showed $83-86 \%$. In 1920 England Midland, Scotland W. and Ireland S. had $84-86 \%$, and in 1924 Ireland S. had $84 \%$. In 1927 England M. had $82 \%$. In I93I, the year supposed to have been destructive for Zostera, England S.W. had 83 and England M. $85 \%$, both districts had $85 \%$ in 1932 and England E. 
had $85 \%$. In I936 England S.W. had $85 \%$ and in I937 England E. had $84 \%$. There is obviously nothing very unusual in the low values which occurred in some districts in I93I and 1932.

Turning to the high values, in I899 England S.W. had I22 \% of the normal sunshine with an average of II4, and in I90I England N.W. had II9. England E. had $115 \%$ in 1906 and England N.W. had $120 \%$ in I9II, which averaged II $5 \%$, the maximum average, followed by the minimum in I9I2. England $M$. had II5 \% in I92I and England S.E. had II6 \% in 1929 and $115 \%$ in 1933.

Table I puts on record the values for the district including Plymouth, namely England S.W. and S. Wales, and the mean values for the ten British Isles districts as usually taken by the Meteorological Office. For neither are the low values of 193I-2 outstandingly low. They have been equalled or surpassed in earlier years.

\section{TABle I. Percentage of NORMal SUnshine}

a, England S.W. and S. Wales (district No. 8) calculated on the normal value to I928, namely $4 \cdot 28 \mathrm{hr}$. a day.

$b$, The ten districts of the British Isles, calculated on the normal, $3.95 \mathrm{hr}$. a day.

\begin{tabular}{|c|c|c|c|c|c|c|c|}
\hline & I 897 & I 898 & I899 & I900 & I90I & I902 & I903 \\
\hline$a$ & I06 & 109 & I 22 & III & III & 97 & 98 \\
\hline \multirow[t]{2}{*}{$b$} & IO4 & 97 & I I 4 & IOO & I I I & 93 & 94 \\
\hline & I904 & 1905 & I906 & I907 & I908 & I909 & I910 \\
\hline$a$ & 99 & IOI & I IO & 98 & $\mathrm{IO2}$ & IO9 & 98 \\
\hline \multirow[t]{2}{*}{$b$} & 99 & IO4 & I I I & 98 & 99 & IO4 & 97 \\
\hline & I9I I & I9I2 & I9I3 & I9I4 & I9I5 & I9I6 & I917 \\
\hline$a$ & II 8 & $8 I$ & 9I & IO4 & IOI & 96 & 99 \\
\hline \multirow[t]{2}{*}{$b$} & II 5 & 83 & 9I & IO4 & IO2 & 89 & 98 \\
\hline & I9I 8 & I9I9 & I920 & I92I & I922 & I923 & I924 \\
\hline \multirow{3}{*}{$\begin{array}{l}a \\
b\end{array}$} & IO4 & I05 & 85 & I I I & 97 & 95 & 89 \\
\hline & IOO & I03 & 90 & I I I & 98 & 96 & 9I \\
\hline & I925 & I926 & I927 & I928 & I929 & I930 & I93 I \\
\hline$a$ & 105 & 93 & 9I & 99 & $\mathrm{II}_{3}$ & 90 & 83 \\
\hline \multirow[t]{2}{*}{$b$} & IOI & 94 & 93 & IOI & I09 & 95 & 89 \\
\hline & I932 & I933 & I934 & I935 & I936 & I937 & \\
\hline$a$ & 85 & 107 & IOO & 97 & 85 & 88 & \\
\hline$b$ & 89 & 106 & I02 & IO4 & 93 & 90 & \\
\hline
\end{tabular}

Table II shows the normal values for the hours of sunshine for the ten districts and the corresponding percentages calculated with respect to the maximum, England S.E., and to the mean. The value for the north of Ireland $3.5 \mathrm{I} \mathrm{hr}$. is only $78 \%$ of the maximum, and only $89 \%$ of the mean. In spite of this Zostera formerly grew well in the north of Ireland, though a reduction of sunshine to $89 \%$ of the mean is suggested as having been the cause of the fatal nature of the Zostera disease.

Furthermore, the illumination due to sunshine in the north of Ireland or of Scotland is on the average less than that in the south of England in which with a midsummer maximum solar altitude of $63^{\circ}$, for latitude $50^{\circ}$, the vertical 
component of the light from sun and sky is about 122 kilolux (Atkins, Ball \& Poole, 1937); for the north of Ireland, around latitude $55^{\circ}$, the maximum altitude is $58^{\circ}$, so the illumination is about II $7 \mathrm{kl}$., similarly with altitude $55^{\circ}$ in the north of Scotland the maximum illumination is around Iro kl. This is to some extent offset by the longer duration of daylight during the summer, though the vertical illumination from a low angle sun is small. Zostera has been reported as growing (Börgesen, I903) as far north as $6 \mathrm{I}^{\circ} 28^{\prime} \mathrm{N}$. in $2-4 \mathrm{~m}$. of water in Vaagfjord in Syderö, the most southerly of the Faeröes. The mean sea temperature at the adjacent Thorshaven is $7.8^{\circ} \mathrm{C}$. with minimum $5.4^{\circ}$ and maximum $10 \cdot 6^{\circ}$. No sunshine records are available for the Faeröes.

\begin{tabular}{|c|c|c|c|}
\hline \multicolumn{4}{|c|}{ ON THE MAXIMUM AND MEAN VALUES } \\
\hline District & Hours & $\%$ & $\%$ \\
\hline Scotland E. & 3.63 & $8 \mathrm{I}$ & 92 \\
\hline England N.E. & 3.93 & 87 & Io \\
\hline England $\mathrm{E}$. & $4 \cdot 32$ & 96 & Io \\
\hline England $M$. & 3.82 & 85 & \\
\hline England S.E. & 4.49 & 100 & \\
\hline Scotland W. & 3.70 & 82 & \\
\hline $\begin{array}{l}\text { England N.W. } \\
\text { and N. Wales }\end{array}$ & 3.89 & 87 & \\
\hline England S.W. & $4 \cdot 28$ & 95 & 108 \\
\hline $\begin{array}{l}\text { and S. Wales } \\
\text { Ireland N. }\end{array}$ & $3 \cdot 5 I$ & 78 & \\
\hline Ireland S. & 3.96 & 88 & \\
\hline Mean & 3.95 & 88 & \\
\hline
\end{tabular}

But the assumption that a greater duration of sunlight necessarily means a greater amount of light is not correct. It has been shown (Atkins, 1938) that though the relation usually holds over a year, it does not always do so, for the altitude of the sun when clear is of great importance. According to photo-electric measurements made at Plymouth the year I93I stood third on the list of eight years $1930-7$, as regards the amount of light received, and 1932 was almost identical with four of the other years. Furthermore, the radiation records at London show that in I93I the amount received was not unusually low but rather above normal.

Finally, with a water plant, one has to consider the extinction coefficient of the water. In estuarine and coastal waters this is subject to large variations, from about 0.2 to 2.5 even in June, thus introducing more than a tenfold variation in the amount of light reaching the plants (Poole \& Atkins, I937; Cooper \& Milne, 1938).

At Plymouth Zostera has been under observation since the opening of the laboratory, as it was always exhibited in one of the aquarium tanks. I am indebted to Dr E. J. Allen for the information that never within his 42 years' experience was there a scarcity of Zostera in any way comparable to the shortage of the last few years. There is certainly no ground for attributing its disappearance to any decrease in illumination leaving the plant, thus weakened, an easier prey to disease. 


\section{SUMMARY}

The suggestion that the enfeeblement of Zostera marina due to lack of sunshine in I93I-2 is the fundamental cause of the epidemic is not supported by the meteorological data available from 1897 onwards, or by the known extinction coefficients of the water.

\section{REFERENCES}

AtKINS, W. R. G., I938. Photo-electric measurements of the seasonal variations in daylight around $0.4 \mathrm{I} \mathrm{m} \mu$. from 1930 to 1937 . Proc. Roy. Soc. A, Vol. I65, pp. $453-65$.

Atkins, W. R. G., Ball, N. G. \& Poole, H. H., I937. The photo-electric measurement of the diurnal variations in daylight in temperate and tropical regions. Proc. Roy. Soc. A, Vol. I60, pp. 526-39.

BÖRGESEN, F., 1903. Botany of the Faeröes, Vol. 2, p. 706.

CoOper, L. H. N. \& Milne, A., I938. The ecology of the Tamar estuary. II. Underwater illumination. Fourn. Mar. Biol. Assoc., Vol. xxir, pp. 509-28.

Poole, H. H. \& AtKINS, W. R. G., I937. The penetration into the sea of light of various wave-lengths as measured by emission or rectifier photo-electric cells. Proc. Roy. Soc. B, Vol. I23, pp. I5I-65.

Tutin, T. G., I938. The autecology of Zostera marina in relation to its wasting disease. New Phytologist, Vol. xxxviI, pp. 50-7I. 